\author{
Aleksander STARAKIEWICZ ${ }^{1}$ \\ Lech LICHOŁAI ${ }^{2}$ \\ Przemysław MIACSIK ${ }^{3}$
}

\title{
CHARAKTERYSTYKA ENERGETYCZNA BUDYNKU JEDNORODZINNEGO OPARTA NA FAKTYCZNYM ZUŻYCIU ENERGII
}

\begin{abstract}
Ilość niezbędnej energii wymaganej do utrzymania komfortu cieplnego budynku i jego mieszkańców zależy od wielu czynników. Są one związane z technologią wykonania, izolacyjnością obudowy i szczelnością budynku, rodzajem i jakością instalacji grzewczych, lokalnymi warunkami klimatycznymi oraz indywidualnymi przyzwyczajeniami mieszkańców. Dla analizowanego budynku jednorodzinnego przedstawiono charakterystyki energetyczne w oparciu o faktyczne zużycie energii do ogrzewania i przygotowania ciepłej wody użytkowej.

Charakterystykę energetyczną obliczoną na podstawie metodologii i obowiązujących norm, wykonano na podstawie dokumentacji technicznej budynku i usprawnień termomodernizacyjnych wykonanych przez użytkownika. Podstawą analizy była baza danych, rzeczywistego zużycia energii elektrycznej, opału i energii z kolektorów słonecznych, zebrana przez użytkownika budynku w latach 2009 - 2015.
\end{abstract}

Słowa kluczowe: zużycie energii konwencjonalnej, energia z kolektorów słonecznych, energia końcowa i pierwotna, wskaźniki zużycia energii

\section{Wprowadzenie}

Każdy budynek w czasie swojego użytkowania spełnia określone funkcje dla realizacji, których wymagane jest dostarczenie odpowiedniej ilości energii. W budynkach mieszkalnych jest ona wykorzystywana na potrzeby ogrzewania i wentylacji, przygotowania ciepłej wody użytkowej, chłodzenia oraz oświetlenia. Ocena energetyczna budynków jest przedmiotem wielu prac badawczych, zarówno krajowych jak i zagranicznych. Ich celem jest wyznaczenie wielkości zużycia energii na określone potrzeby, identyfikacja strat i możliwości ich zmniejszenia. Aby określić efektywność wykorzystania energii, należy poznać zapotrzebowanie na energię każdego z tych elementów, zarówno od strony po-

\footnotetext{
${ }^{1}$ Autor do korespondencji / corresponding author: Aleksander Starakiewicz, Politechnika Rzeszowska, Zakład Budownictwa Ogólnego, ul. Poznańska 2, 35-959 Rzeszów; tel. 178651428; olekstar@prz.edu.pl 2 Lech Lichołai, Politechnika Rzeszowska; tel. 178651327; Lech.Licholai@ prz.edu.pl

3 Przemysław Miąsik, Politechnika Rzeszowska; tel. 178651702; pmiasik@ prz.edu.pl
} 
trzeb netto (energia użytkowa), energii dostarczanej brutto po uwzględnieniu strat (energia końcowa), ale również z uwzględnieniem źródła pochodzenia energii (energia pierwotna). Szacowanie zużywanej energii może odbywać się zarówno na podstawie obliczeń teoretycznych, ale i pomiarów faktycznego zużycia energii. Stąd też uzasadnione jest przedstawienie szerszego spojrzenie na potrzeby energetyczne $\mathrm{w}$ budynku mieszkalnym, rejestrowane na przestrzeni kilku ostatnich lat. Wybrane aspekty tego zagadnienia były już poruszane na poprzednich Konferencjach Solina 2008 i 2010 [1,2]. Zagadnienie zużycia energii $\mathrm{w}$ budynkach jest ciągle aktualne $\mathrm{z}$ uwagi na jej ograniczanie poprzez akty prawne, [3] ale również ze względu na ochronę środowiska naturalnego człowieka (zmniejszenie emisji gazów cieplarnianych, pyłów, wykorzystywanie odnawialnych źródeł energii) $[4,5]$.

\section{Metodyka wyznaczania charakterystyki energetycznej opartej na faktycznym zużyciu energii}

Możliwość obliczeń metodą faktycznego zużycia energii wprowadziło Rozporządzenie Ministra Infrastruktury i Rozwoju z dnia 27 lutego 2015 r. [6] i na jego podstawie opracowano metodykę przedstawioną poniżej. Stosowanie tej metody do obliczania charakterystyki energetycznej budynku jest dopuszczalne, jeżeli spełnione są następujące warunki: 1. w analizowanym budynku systemy ogrzewania lub przygotowania ciepłej wody użytkowej są zasilane z sieci ciepłowniczej lub gazowej; 2. zużycie ciepła rozlicza się w oparciu o wskazania ciepłomierza; 3. zużycie gazu ziemnego rozlicza się w oparciu o wskazania gazomierza; 4. zużycie ciepłej wody użytkowej rozlicza się w oparciu o wskazania wodomierza; 5 . budynek nie jest wyposażony w system chłodzenia; 6 . istnieją dokumenty potwierdzające rzeczywiste zużycie ciepła lub gazu ziemnego z ostatnich 3 lat poprzedzających sporządzenie charakterystyki energetycznej budynku; 7. w okresie, który poprzedza sporządzenie charakterystyki energetycznej budynku, a z którego przyjęto dokumenty potwierdzające rzeczywiste zużycie ciepła lub gazu ziemnego, nie przeprowadzono robót budowlanych wpływających na charakterystykę energetyczną; 8. gaz ziemny zużywany jest wyłącznie na potrzeby ogrzewania lub przygotowania ciepłej wody użytkowej; 9. możliwe jest określenie powierzchni budynku o regulowanej temperaturze powietrza.

Obliczenia bilansu energetycznego istniejącego budynku zostały oparte na Rozporządzeniu Ministra Infrastruktury z dnia 27 lutego 2015 r. [6], pomimo iż charakterystyka energetyczna analizowanego budynku, zgodnie z zapisami wyżej wymienionego Rozporządzenia, nie powinna być przeprowadzona metodą faktycznego zużycia. Wynika to z faktu, nie spełnienia przez budynek wszystkich wymagań stawianych obiektom, które mogą być poddane analizie metodą opartą na faktycznym zużyciu energii. Przeprowadzone w kolejnym rozdziale obliczenia mają na celu wykazanie, że metodę tę można stosować również w innych warunkach a nie tylko tych określonych w Rozporządzeniu. 
Wzory prezentowane poniżej, niewystępujące w metodologii, posiadają własne modyfikacje dostosowane do paliwa stałego i innych źródeł energii końcowej. Uzyskane wyniki obliczeń zostaną porównane z wynikami metody opartej na standardowym sposobie użytkowania budynku.

Roczne zapotrzebowanie na energię końcową dostarczoną do budynku dla systemu ogrzewania i systemu przygotowania ciepłej wody użytkowej oraz przez instalację kolektorów słonecznych $\mathrm{Q}_{\mathrm{k}, \mathrm{H}+\mathrm{W}}$ dla kilku rodzajów paliwa stałego wyznacza się ze zmodyfikowanego wzoru [6]:

$$
Q_{k, H+W}=\frac{\sum_{i} Q_{k, H+W, i}}{3}+\frac{Q_{k, W, s o l}}{3}=\frac{\sum_{i}\left(C_{H+W, i} \cdot W_{o, i}\right)}{3,6 * 3}+\frac{Q_{k, W, s o l}}{3}\left[\frac{k W h}{r o k}\right]
$$

gdzie: $\mathrm{Q}_{\mathrm{k}, \mathrm{H}+\mathrm{W}, \mathrm{i}}$ - zapotrzebowanie na energię końcową dostarczaną do budynku dla $i$-tego paliwa stałego na potrzeby ogrzewania i przygotowania ciepłej wody użytkowej z ostatnich 3 lat, $\left[\frac{\mathrm{kWh}}{\mathrm{rok}}\right] \mathrm{w} \mathrm{kWh} / \mathrm{rok}\left[\frac{\mathrm{kWh}}{\mathrm{rok}}\right]$;

$\mathrm{Q}_{\mathrm{k}, \mathrm{W}, \mathrm{sol}}$ - energia końcowa dostarczana do budynku na potrzeby przygotowania ciepłej wody użytkowej przez instalację kolektorów słonecznych $\mathrm{z}$ ostatnich 3 lat, w $\mathrm{kWh} /$ rok;

$\mathrm{C}_{\mathrm{H}+\mathrm{W}, \mathrm{i}} \mathrm{C}_{\mathrm{W}, 3}$ - suma zużycia $i$-tego paliwa stałego na potrzeby ogrzewania i przygotowania ciepłej wody użytkowej z ostatnich 3 lat poprzedzających wydanie świadectwa charakterystyki energetycznej, wyznaczana na podstawie dokumentów potwierdzających rzeczywiste zużycie, w kg; $\mathrm{W}_{\mathrm{o}, \mathrm{i}}$ - wartość opałowa $i$-tego paliwa stałego określona w oparciu o dane udostępnione przez dostawcę paliwa stałego z ostatnich 3 lat, w MJ/kg;

Roczne zapotrzebowanie na energię pomocniczą końcową dostarczoną do budynku dla systemów technicznych $\mathrm{E}_{\mathrm{el}, \mathrm{pom}, \mathrm{H}+\mathrm{w}} \mathrm{E}_{\mathrm{el}, \mathrm{pom}}$ wyznacza się ze wzoru [6]:

$$
E_{e l, p o m, H+W}=\sum_{j} E_{e l, p o m, H+W, j} \quad\left[\frac{k W h}{r o k}\right]
$$

gdzie: $E_{e l, p o m, H+W, j}$ - roczne zapotrzebowanie na energię pomocniczą końcową dostarczaną do budynku dla j-tego systemu technicznego na potrzeby ogrzewania i przygotowania ciepłej wody użytkowej, w kWh/rok;

Roczne zapotrzebowanie na energię końcową dostarczoną do budynku dla i przez systemy techniczne $Q_{k}$ wyznacza się ze wzoru [6]:

$$
Q_{k}=Q_{k, H+W}+E_{e l, p o m, H+W} \quad\left[\frac{k W h}{r o k}\right]
$$


Roczne zapotrzebowanie na nieodnawialną energię pierwotną dla systemów technicznych $\mathrm{Q}_{\mathrm{p}}[\mathrm{kWh} / \mathrm{rok}$ ] w budynku wyznacza się ze wzoru [6]:

$$
Q_{p}=Q_{p, H+W}+Q_{p, p o m}=\sum_{i}\left(Q_{k, H+W, i} \cdot w_{H+W, i}\right)+E_{e l, p o m, H+W} \cdot w_{e l}
$$

gdzie: $\mathrm{Q}_{\mathrm{p}, \mathrm{H}+\mathrm{W}}$ - roczne zapotrzebowanie na energię pierwotną dostarczaną do budynku na potrzeby ogrzewania i przygotowania ciepłej wody użytkowej, w kWh/rok;

$\mathrm{Q}_{\mathrm{p}, \text { pom }}$ - roczne zapotrzebowanie na energię pomocniczą pierwotną dostarczoną do budynku dla systemów technicznych na potrzeby ogrzewania i przygotowania ciepłej wody użytkowej, w $\mathrm{kWh} / \mathrm{rok}$;

$\mathrm{w}_{\mathrm{H}+\mathrm{W}, \mathrm{i}}$ - współczynnik nakładu nieodnawialnej energii pierwotnej na wytworzenie i dostarczenie nośnika energii lub energii dla systemów technicznych na potrzeby ogrzewania i przygotowania ciepłej wody użytkowej;

$\mathrm{W}_{\mathrm{el}} \mathrm{W}_{\mathrm{el}}$ - współczynnik nakładu nieodnawialnej energii pierwotnej na wytworzenie i dostarczenie energii elektrycznej, dla systemów technicznych na potrzeby ogrzewania i przygotowania ciepłej wody użytkowej.

Wyznaczenie wskaźników rocznego zapotrzebowania na energię EP, EK i EU w budynku wyznacza się ze wzorów [6] dla:

1) nieodnawialnej energii pierwotnej:

$$
E P_{H+W}=\frac{Q_{p, H+W}}{A_{f}} \quad\left[\frac{k W h}{m^{2} \cdot r o k}\right]
$$

2) energii końcowej:

$$
E K_{H+W}=\frac{Q_{k, H+W}}{A_{f}} \quad\left[\frac{k W h}{m^{2} \cdot r o k}\right]
$$

Rocznego zapotrzebowania na energię użytkową $\mathrm{Q}_{\mathrm{u}} \mathrm{w}$ budynku nie wyznacza się, jeżeli budynek posiada system ogrzewania i system przygotowania ciepłej wody użytkowej zasilane z jednego źródła energii.

\section{Opis konstrukcji budynku oraz systemów ogrzewania i przygotowania ciepłej wody użytkowe}

Analizowany obiekt to wolnostojący piętrowy budynek jednorodzinny, całkowicie podpiwniczony, $\mathrm{z}$ nieogrzewanym strychem przykryty dachem czterospadowym zlokalizowany w Rzeszowie. Budynek jest zamieszkiwany przez czteroosobową rodzinę dwupokoleniową, wcześniej przez sześcioosobową trzypokole- 
niową. W nieogrzewanym podpiwniczeniu znajduje się garaż, magazyn, kotłownia, spiżarnia, klatka schodowa i skład opału. Na parterze znajdują się pomieszczenia: ganek, hol, klatka schodowa, kuchnia, dwa pokoje i łazienka ogólna. Na piętrze rozmieszczenie pomieszczeń jest identyczne. Ściany zewnętrzne wykonane są w technologii dwuwarstwowej, warstwa konstrukcyjna to mur z cegły ceramicznej pełnej $40 \mathrm{~cm}$ a warstwa izolacji termicznej to styropian $10 \mathrm{~cm}$. Budynek poddawany był etapowej termomodernizacji. Docieplenie ścian zewnętrznych zrealizowano w 1990 roku w technologii lekkiej-mokrej a w 2005 roku przeprowadzono docieplenie stropu nad piwnicą (przyklejono $5 \mathrm{~cm}$ styropianu do sufitu) oraz stropu nad piętrem. W latach 1998-2002 wymieniono okna skrzynkowe na jednoramowe drewniane $\left(U_{\mathrm{f}}=1,45 \mathrm{~W} / \mathrm{m}^{2} \mathrm{~K}\right) \mathrm{z}$ oszkleniem $\left(\mathrm{U}_{\mathrm{g}}=1,1 \mathrm{~W} / \mathrm{m}^{2} \mathrm{~K}\right)$, na klatce schodowej z oszkleniem $\left(\mathrm{U}_{\mathrm{g}}=0,6 \mathrm{~W} / \mathrm{m}^{2} \mathrm{~K}\right)$. System grzewczy w budynku stanowi instalacja c.o. w której źródłem ciepła jest kocioł stalowy z górnym spalaniem paliwa stałego o sprawności nominalnej 82\%. Kocioł c.o. jest źródłem ciepła dla instalacji c.o. i instalacji ciepłej wody użytkowej. Elementami grzejnymi w całym budynku stanowią grzejniki żeliwne wyposażone w zawory termostatyczne a w łazienkach grzejniki drabinkowe. Instalacja grzewcza wyposażona jest w pompę obiegową zsynchronizowaną z pracą kotła c.o. Przewody rozprowadzające czynnik grzewczy są zaizolowane (wełna szklana, owijka, gips) i poprowadzone pod sufitem w pomieszczeniach piwnicy. Instalacja ciepłej wody użytkowej zasilana jest dodatkowo z kolektorów słonecznych. W rozważanym budynku jednorodzinnym c.w.u. przygotowywana jest centralnie i gromadzona w zasobniku biwalentnym o pojemności 300 litrów. Zasobnik posiada dwie wężownice, gdzie dolna zasilana jest $\mathrm{z}$ instalacji słonecznej a górna $\mathrm{z}$ instalacji c.o. Instalacja słoneczna składa się z dwóch kolektorów o łącznej, czynnej powierzchni absorbera $4,70 \mathrm{~m}^{2}$. Kolektory skierowane są na południe i ustawione pod kątem $55^{\circ}$ do poziomu [2]. Temperatura powietrza wewnętrznego budynku w analizowanym okresie utrzymywana była na poziomie $20-21,5^{\circ} \mathrm{C}$.

\section{Charakterystyka energetyczna budynku oparta na pomiarach faktycznie zużytej ilości energii}

W rozdziale tym przedstawiono wyniki faktycznego zużycia energii w budynku jednorodzinnym opracowane na podstawie pomiarów wykonanych od 1.01.2009 r. do 31.12.2015 r. Do analizy wybierano 3 kolejne lata w różnych okresach. Opał stosowany w budynku to węgiel kamienny oraz drewno. Dane wyjściowe to zarejestrowana ilość zużytego opału w kilogramach, przeliczona na wartość energii w kilowatogodzinach przyjmując kaloryczność w zależności od roku zakupu. Całkowite zużycie energii z węgla kamiennego i drewna na potrzeby ogrzewania i wentylacji oraz przygotowania ciepłej wody użytkowej, energii pochodzącej z kolektorów słonecznych do podgrzewania c.w.u. oraz energii elektrycznej zużywanej przez system ogrzewczy i przygotowania ciepłej wody użytkowej zestawiono w tabeli 1, [7]. 
Tabela 1. Zużycie energii w systemie ogrzewania i ciepłej wody użytkowej w latach 2009-2015

Table 1. Consumption of energy in the heating system and hot water in 2009-2015

\begin{tabular}{|c|c|c|c|c|c|c|c|c|c|}
\hline \multirow[b]{2}{*}{ Rok } & \multicolumn{2}{|c|}{$\begin{array}{c}\text { Energia elekt. } \\
\text { pomocnicza }\end{array}$} & \multicolumn{3}{|c|}{ Węgiel kamienny } & \multicolumn{3}{|c|}{ Drewno } & \multirow{2}{*}{\begin{tabular}{|c|}
$\begin{array}{c}\text { Kolektory } \\
\text { słoneczne }\end{array}$ \\
Energia \\
$\mathrm{Q}_{\mathrm{k}, \mathrm{W}, \mathrm{sol}}$ \\
\end{tabular}} \\
\hline & $\begin{array}{c}\text { Instal. } \\
\text { c.o. } \\
\text { Eel,pom,H } \\
\end{array}$ & \begin{tabular}{|c|} 
Insta. \\
kol.sł. \\
Eel,pomw \\
\end{tabular} & $\begin{array}{c}\text { Zużycie } \\
\mathrm{C}_{\mathrm{H}+\mathrm{W}, \mathrm{i}}\end{array}$ & $\begin{array}{c}\text { Wartość } \\
\text { opałowa } \\
\mathrm{W}_{\mathrm{o}, \mathrm{i}} \\
\end{array}$ & $\begin{array}{l}\text { Energia } \\
\mathrm{Q}_{\mathrm{k}, \mathrm{H}+\mathrm{W}, \mathrm{i}}\end{array}$ & $\begin{array}{c}\text { Zużycie } \\
\mathrm{C}_{\mathrm{H}+\mathrm{W}, \mathrm{i}}\end{array}$ & $\begin{array}{c}\text { Wartość } \\
\text { opałowa } \\
\mathrm{W}_{\mathrm{o}, \mathrm{i}}\end{array}$ & $\begin{array}{l}\text { Energia } \\
\mathrm{Q}_{\mathrm{k}, \mathrm{H}+\mathrm{W}, \mathrm{i}}\end{array}$ & \\
\hline- & $\begin{array}{l}\mathrm{kWh}] \\
\end{array}$ & [kWh] & {$[\mathrm{kg}]$} & \begin{tabular}{|l|}
{$[\mathrm{MJ} / \mathrm{kg}]$} \\
\end{tabular} & [kWh] & {$[\mathrm{kg}]$} & {$[\mathrm{MJ} / \mathrm{kg}]$} & {$[\mathrm{kWh}]$} & {$[\mathrm{kWh}]$} \\
\hline 1 & 2 & 3 & 4 & 5 & 6 & 7 & 8 & 9 & 10 \\
\hline 2009 & 107,9 & 24,09 & 3725 & 25,0 & 25868,1 & 1155,0 & 15,25 & 4892,7 & 4610,0 \\
\hline 2010 & 64,9 & 24,51 & 4046 & 25,5 & 28659,2 & 988,0 & 15,25 & 4185,3 & 3706,5 \\
\hline 2011 & 95,9 & 9,06 & 3114 & 28,0 & 24220,0 & 1746,0 & 15,25 & 7396,3 & 1756,0 \\
\hline 2012 & 128,0 & 10,98 & 2878 & 29,0 & 23183,9 & 2020,0 & 15,25 & 8556,9 & 1536,0 \\
\hline 2013 & 108,0 & 8,48 & 2973 & 30,0 & 24775,0 & 871,0 & 15,25 & 3689,7 & 1136,0 \\
\hline 2014 & 97,2 & 7,92 & 2544 & 29,5 & 20846,7 & 811,0 & 15,25 & 3435,5 & 1033,0 \\
\hline 2015 & 128,7 & 8,10 & 2730 & 29,0 & 21991,7 & 725,0 & 15,25 & 3071,2 & 1035,0 \\
\hline Średnia & 104,4 & 13,30 & 3144 & 28,0 & 24220,6 & 1188,0 & 15,25 & 5032,5 & 2116,1 \\
\hline
\end{tabular}

Obliczenia rocznego zapotrzebowanie na energię końcową $\mathrm{Q}_{\mathrm{k}}$ i pierwotną $\mathrm{Q}_{\mathrm{p}}$ dostarczoną do budynku dla systemu ogrzewania i systemu przygotowania ciepłej wody użytkowej dla dwóch rodzajów paliwa stałego (węgiel i drewno), przez instalację kolektorów słonecznych $\mathrm{Q}_{\mathrm{k}, \mathrm{H}+\mathrm{w}}$ oraz wskaźników zużycia energii końcowej EK i pierwotnej EP dla 3-letnich okresów obliczeniowych przedstawiono w tablicy 2. Do obliczeń przyjęto następujące wartości współczynników nakładu nieodnawialnej energii pierwotnej na wytworzenie i dostarczenie nośnika energii dla systemów technicznych na potrzeby ogrzewania i przygotowania ciepłej wody użytkowej: węgiel kamienny $\mathrm{w}_{\mathrm{H}+\mathrm{w}, 1}=1,1$; drewno $\mathrm{w}_{\mathrm{H}+\mathrm{w}, 2}=0,2$; energia słoneczna $\mathrm{w}_{\mathrm{H}+\mathrm{W}, 3}=0$; energia elektryczna $\mathrm{w}_{\mathrm{el}}=3$. Powierzchnia ogrzewana rozpatrywanego budynku wynosi $\mathrm{A}_{\mathrm{f}}=109,82 \mathrm{~m}^{2}$.

Wskaźnik rocznego zapotrzebowania na nieodnawialną energię pierwotną analizowanego budynku, obliczony metodą szczegółową wg metodologii [6] wynosi $\mathrm{EP}_{\mathrm{H}+\mathrm{W}}=291,4\left[\mathrm{kWh} / \mathrm{m}^{2} \mathrm{rok}\right]$.

$$
\begin{aligned}
& Q_{p, 2013-2015}=Q_{p, H+W}+Q_{p, p o m}=\sum_{i}\left(Q_{k, H+W, i} \cdot w_{H+W, i}\right)+E_{e l, p o m, H+W} \cdot w_{e l}= \\
& =\frac{24775,0+20846,7+21991,7}{3} \cdot 1,1+\frac{3689,7+3435,5+3071,2}{3} \cdot 0,2+ \\
& +\frac{1136+1033+1035}{3} \cdot 0,0+\frac{108+97,2+128,7}{3} \cdot 3,0+\frac{8,48+7,92+8,1}{3} \cdot 3,0= \\
& =25829,7 \quad[\mathrm{kWh} / \mathrm{rok}]
\end{aligned}
$$


Tabela 2. Wskaźniki rocznego zapotrzebowania na energię pierwotną EP i energię końcową EK Table 2. Pointers of annual demand into primary energy EP and final energy EK

\begin{tabular}{|c|c|c|c|c|c|c|}
\hline Rok & $\begin{array}{c}\text { Roczny } \\
\text { wskaźnik } \\
\mathrm{EP}_{\mathrm{H}+\mathrm{W}}\end{array}$ & $\begin{array}{c}\text { Okres 3 lat } \\
\text { oceny } \\
\text { budynku }\end{array}$ & $\begin{array}{c}\text { Energia } \\
\text { końcowa } \\
\mathrm{Q}_{\mathrm{k}, \mathrm{H}+\mathrm{W}}\end{array}$ & $\begin{array}{c}\text { Energia } \\
\text { pierwotna } \\
\mathrm{Q}_{\mathrm{p}, \mathrm{H}+\mathrm{W}}\end{array}$ & $\begin{array}{c}\text { Wskaźnik } \\
\mathrm{EK}\end{array}$ & $\begin{array}{c}\text { Wskaźnik } \\
\mathrm{EP} / \mathrm{m}_{\mathrm{H}+\mathrm{W}}\end{array}$ \\
\hline 1 & 2 & $\mathrm{kWh}$ & $\mathrm{kWh}$ & $\mathrm{kWh} / \mathrm{m}^{2} \mathrm{rok}$ & $\mathrm{kWh} / \mathrm{m}^{2}$ rok \\
\hline 2009 & 271,6 & - & - & - & - & - \\
\hline 2010 & 297,1 & - & - & - & - & - \\
\hline 2011 & 258,9 & $2009-2011$ & 35206,8 & 30298,6 & 320,6 & 275,9 \\
\hline 2012 & 251,6 & $2010-2012$ & 34511,1 & 29565,7 & 314,3 & 269,2 \\
\hline 2013 & 258,1 & $2011-2013$ & 32203,4 & 28135,5 & 293,2 & 256,2 \\
\hline 2014 & 217,9 & $2012-2014$ & 29517,7 & 26634,8 & 268,8 & 242,5 \\
\hline 2015 & 229,6 & $2013-2015$ & 27124,0 & 25829,7 & 247,0 & 235,2 \\
\hline Średnia & $\mathbf{2 5 5 , 0}$ & $\mathbf{2 0 0 9 - 2 0 1 5}$ & $\mathbf{3 1 7 1 2 , 6}$ & $\mathbf{2 8 0 9 2 , 9}$ & $\mathbf{2 8 8 , 8}$ & $\mathbf{2 5 5 , 8}$ \\
\hline
\end{tabular}

\section{Analiza wyników}

Przedstawione wyniki obliczeń mają charakter analityczno-badawczy gdyż: z jednej strony, w rozumieniu obowiązującej metodologii [6] nie mogą być traktowane jak charakterystyka energetyczna budynku oparta na faktycznym zużyciu energii pochodzącej z paliwa stałego, zaś z drugiej strony potwierdzają słuszność przyjętej do obliczeń metody. Metodologia [6] w tego rodzaju analizie nie wprowadza obowiązku uwzględnienia warunków klimatycznych z rozważanego okresu.

Wskaźniki rocznego zapotrzebowania na nieodnawialną energię pierwotną $\mathrm{EP}_{\mathrm{H}+\mathrm{W}} \mathrm{w}$ kolejnych latach (2009-2015) odzwierciedlają wartości rzeczywistego zużycia energii. Są one w większości lat niższe od wartości wskaźnika uzyskanej na podstawie obliczeń wg obowiązującej metodologii. Różnica wskaźników w tym okresie zawiera się między $+2,0 \%$ a $-25,2 \%$, natomiast dla wartości średniej wynosi $-12,5 \%$. Wskaźniki te wskazują wpływ warunków klimatycznych, tj. mroźne (2010) i łagodne (2014) zimy. Średnie zewnętrzne temperatury powietrza w 2010 roku były następujące: dla zimy $-3,5^{\circ} \mathrm{C}$ (dla 30 -lecia $-2,0{ }^{\circ} \mathrm{C}$ ); dla stycznia $-7,5^{\circ} \mathrm{C}$ (dla 30-lecia $-2,5^{\circ} \mathrm{C}$ ); dla grudnia $-4,5^{\circ} \mathrm{C}$ (dla 30 -lecia $-1,0^{\circ} \mathrm{C}$ ). Natomiast dla 2014 roku temperatury były następujące: dla zimy $+1,0{ }^{\circ} \mathrm{C}$ (dla 30-lecia $-2,0{ }^{\circ} \mathrm{C}$ ); dla stycznia $-0,5^{\circ} \mathrm{C}$ (dla 30 -lecia $-2,5^{\circ} \mathrm{C}$ ); dla grudnia $+1,0{ }^{\circ} \mathrm{C}$ (dla 30 -lecia $-1,0{ }^{\circ} \mathrm{C}$ ). Wskaźniki zapotrzebowania na energię pierwotną $\mathrm{EP}_{\mathrm{H}+\mathrm{W}} \mathrm{z}$ 3-letnich okresów pomiarowych prezentują wartości średniego zużycia energii i nie pokazują dynamiki poszczególnych lat. Różnica 3-letnich wskaźników od ich wartości średniej wynosi od $+7,9 \%$ do $-8,1 \%$. Średnie wartości wskaźników z „okresu 7 lat” i pięciu „3-letnich okresów” są bardzo zbliżona do siebie, różnica to zaledwie $0,32 \%$.

Wnioski z przeprowadzonej analizy są następujące:

1. W metodzie faktycznego zużycia energii okres rozliczeniowy powinien wynosić więcej niż 3 lata, co najmniej 7 lat. Eliminujemy w ten sposób okresy minimalnego i maksymalnego zużycia energii w budynku a wskaźnik jej zużycia jest bardziej miarodajny. 
2. Wskaźniki zapotrzebowania na nieodnawialną energię pierwotną $\mathrm{EP}_{\mathrm{H}+\mathrm{W}}$ z dowolnych 3-letnich okresów pomiarowych są zdecydowanie niższe od wskaźnika obliczonego metodą szczegółową wg metodologii [6].

3. Wskazane jest opracowanie metody faktycznego zużycia energii uwzględniającej warunki klimatyczne z rozważanego okresu.

\section{Literatura}

[1] Starakiewicz A.: Badania zużycia energii na potrzeby bytowe w budynku mieszkalnym, ZN PRz nr 252, Budownictwo i Inżynieria Środ. Nr 47, 2008, s. 477-481.

[2] Starakiewicz A.: Eksploatacja instalacji c.w.u. z kolektorami słonecznymi w budynku mieszkalnym, ZN PRz nr 271, Bud. i Inżynieria Środ. nr 57, 4/2010, s. 509-513.

[3] Rozporządzenie Ministra Transportu, Budownictwa i Gospodarki Morskiej z dnia 5 lipca 2013 r. w sprawie warunków technicznych, jakim powinny odpowiadać budynki i ich usytuowanie, Dz. U. z 13 sierpnia 2013 r., poz. 926.

[4] Dyrektywa Parlamentu Europejskiego i Rady 2010/31/UE z dnia 19 maja 2010 r. ws. charakterystyki energetycznej budynków, Dz. Urz. UE L 153 z 18.06.2010, str 13.

[5] Dyrektywa Parlamentu Europejskiego i Rady 2009/28/UE z dnia 23 kwietnia 2009 r. ws. promowania stosowania energii ze źródeł odnawialnych zmieniająca i w następstwie uchylająca dyrektywy 2001/77/WE oraz 2003/30/WE, Dz. Urz. UE L 140 z 5.06.2009, str 16.

[6] Rozporządzenie Ministra Infrastruktury i Rozwoju z dnia 27 lutego 2015 r. w sprawie metodologii wyznaczania charakterystyki energetycznej budynku lub części budynku oraz świadectw charakterystyki energet., Dz. U. z 18 marca 2015 r., poz. 376.

[7] Starakiewicz A., Lichołai L., Miąsik P., Krasoń J.: Zużycie nośników energii w budynku jednorodzinnym na cele ogrzewania, ciepłej wody użytkowej i potrzeb bytowych, Czasopismo Inżynierii Lądowej, Środowiska i Architektury - Journal of Civil Engineering, Environment and Architecture, JCEEA, t. XXXIII, z. 63 (3/16), 2016, s. 439-446, DOI:10.7862/rb.2016.227.

\section{ENERGY PERFORMANCE OF RESIDENTIAL BUILDING BASED ON ACTUAL ENERGY CONSUMPTION}

\section{S u m m a r y}

The necessary amount of energy required to maintain the comfort of the building and its occupants depends on many factors. They are associated with the technology you-agony, housing insulation and the tightness of the building, the type and quality of in-heating installations, local climatic conditions and the individual habits of the residents. For the analyzed single-family building shows the characteristics of energy based on actual consumption of energy for heating and domestic hot water. The energy performance calculated on the basis of the methodology and standards, were made on the basis of the technical documentation of the building and modernization measures taken by the user. The analysis was the database, the actual consumption of electricity, fuel and energy co-teachers solar, collected by the user of the building in the years 2009-2015.

Keywords: consumption of conventional energy, energy from solar collectors, final energy and primary indicators of energy consumption

Przestano do redakcji: 26.01.2017 r.

Przyjęto do druku: 31.03.2017 r. 